\title{
The hydrocarbon potential of the offshore Talara Basin, Peru
}

\author{
*Eduardo A. Rossello ${ }^{1}$, Stephen P.J. Cossey², Guzmán Fernández ${ }^{3}$
}

\author{
1 Instituto de Geociencias Básicas, Aplicadas y Ambientales de Buenos Aires (CONICET-IGEBA), Universidad de Buenos Aires, Facultad \\ de Ciencias Exactas y Naturales (FCEN), Ciudad Universitaria, 1428, Buenos Aires, Argentina. ORCID: 0000-0002-6466-9956. \\ ea_rossello@yahoo.com.ar \\ 2 Cossey and Associates Inc., P.O. Box 1510, Durango, CO 81302, U.S.A. ORCID: 0000-0002-3393-6505. \\ cosseygeo@aol.com \\ 3 Independent Consultant, Sanlucar 1491, Of. 201, Montevideo, Uruguay. \\ guzman.fernandez@field-intelligence.com
}

*Corresponding author:ea_rossello@yahoo.com.ar

\begin{abstract}
The offshore Talara Basin is the western extension of the hydrocarbon producing onshore fields since the mid-1800s area of Peru and is also located above the subduction zone of the active continental margin of South America. The offshore portion was evaluated using high quality 3D seismic where mapping horizons are all unconformities within the Eocene as well as the unconformities at the top Paleocene and top Cretaceous. Possible source rocks are the Cretaceous black marine shales of the Campanian Redondo Formation, the limestones of the Albian Muerto Formation, and the marine shales of the Paleogene. The primary target offshore is expected to be deep-water turbidites of Paleocene/Eocene age with a depositional source from the northeast from highlands created by the compressional uplift of the Andes. The main seals offshore are expected to be shales of the upper Eocene Lagunitos Formation and shales in the Chacra Formation, which are also seals in the onshore Litoral field. Thermal maturation modeling shows that two hydrocarbon kitchens exist in the offshore portion of the Talara basin, one in the north and another in the south. The probable Cretaceous source rocks reached the onset of maturity ( $\mathrm{VR}=0.63 \%)$ at a depth of 3,250 to $3,285 \mathrm{~m}(10,663-10,778 \mathrm{ft}$ ) between 30 and $39 \mathrm{Ma}$ (Late Eocene to Oligocene). Importantly, the Cretaceous source rocks stay within the oil window once they enter it in the late Eocene. Satellite studies show a large offshore present-day oil seep in the southern part of the basin and 3D seismic shows direct hydrocarbon indicators (DHIs) imaged as flat spots and bottom simulating reflectors (BSR). Basin modeling suggests hydrocarbon migration pathways would have been updip (to the east) into the onshore traps and would therefore have first filled the offshore traps along the migration pathway. We conclude that the Talara Basin offshore offers excellent exploration opportunities in a proven productive area where multiple prospects have been mapped.
\end{abstract}

Keywords: Hydrocarbon potential, Offshore exploration, Talara basin, Peru.

RESUMEN. Potencial de hidrocarburos de la cuenca Talara costa afuera, Perú. La cuenca Talara costa afuera es la extensión occidental de su parte continental que contiene los campos petroleros productores de hidrocarburos desde mediados del siglo XIX en Perú. Esta se encuentra sobre la zona de subducción en el margen activo de los Andes, donde la placa oceánica de Nazca está subduciendo bajo la continental de América del Sur. La porción marina de la cuenca se evaluó utilizando un relevamiento sísmico 3D de alta calidad donde los horizontes de mapeo interpretados son discordancias dentro del Eoceno, así como del Paleoceno superior y el Cretácico Superior. Las posibles rocas generadoras son las lutitas marinas negras del Cretácico de la Formación Redondo (Campaniano), las calizas de la Formación Muerto (Albiano) y las lutitas marinas del Terciario temprano. Se propone que el objetivo principal de la exploración petrolera en alta mar sean las turbiditas de aguas profundas del Paleoceno/Eoceno originadas por aportes desde las tierras altas del noreste, 
creadas por la elevación compresiva de los Andes. Se considera que los principales sellos en el sector costa afuera sean lutitas de la Formación Lagunitos del Eoceno superior y las lutitas de la Formación Chacra, que también son sellos en el campo terrestre Litoral. El modelo de maduración térmica muestra que existen dos cocinas de hidrocarburos en la parte costa afuera de la cuenca, una en el norte y otra en el sur. La fuente probable del Cretácico alcanzó el inicio de la madurez $(\mathrm{VR}=0,63 \%)$ a una profundidad de 3.250 a $3.285 \mathrm{~m}$ (10.663-10.778 pies) entre 30 y 39 Ma (Eoceno tardío al Oligoceno). Es importante destacar que las rocas generadoras del Cretácico permanecen dentro de la ventana de petróleo al ingresar en el Eoceno tardío. Los estudios satelitales muestran una gran emanación actual de petróleo en alta mar, en la parte sur de la cuenca y la sísmica 3D presenta indicadores directos de hidrocarburos (DHI) en imágenes como puntos planos y reflectores de simulación de fondo (BSR). El modelado de cuencas sugiere que las vías de migración de los hidrocarburos habrían sido ascendentes hacia el este, en dirección a las trampas en tierra y, por lo tanto, habrían llenado primero las trampas en alta mar a lo largo de la vía de migración. Se concluye que la cuenca Talara costa afuera ofrece excelentes oportunidades de exploración en un área productiva probada donde se han identificado múltiples prospectos.

Palabras clave: Potencial de hidrocarburos, Exploración costa afuera, Cuenca Talara, Perú.

\section{Introduction}

The undrilled deep-water Talara Basin is located along the northern Pacific margin of Peru (Travis et al., 1975). It is the western extension of the Cretaceous and Paleogene-Neogene stratigraphy of the large, traditional reservoirs in the onshore Talara Basin oilfields. Higley (2004) mentioned a production of 1.68 billion barrels of oil in the last approximately 130 years. This basin is also located above the subduction zone of the active margin of South America, where the oceanic Nazca plate is subducting under the continental South American plate (Diniz et al., 2010; Espurt et al., 2018; Lemgruber-Traby et al., 2020).

Current daily production from onshore Eocene sandstone reservoirs is around 15,000 boe from more than 2,600 active wells in an area of $460 \mathrm{~km}^{2}$ (Perupetro, 2020'). Well depths range between 500 and $2,800 \mathrm{~m}$. The average oil gravity is around $33^{\circ} \mathrm{API}\left(25^{\circ}-42^{\circ}\right.$ range) (Hinoztrosa and Espinoza, 2005 ) with very low sulphur content. The estimated remaining potential recoverable volume could reach almost 120 MMboe. Several secondary recovery projects have been implemented since 2003, with excellent results.

The western boundary and the unexplored offshore portions of the Talara basin are poorly defined (Figs. 1, 2). The onshore (eastern) margin is bounded by Paleozoic basement exposed in the Amotape Mountains and the southern Silla de Paita. The Amotape Mountains extend at a $60^{\circ}$ angle from the Andes and, along with the Tamarindo High, separate the Talara basin from the Lancones basin (Valencia and Uyen, 2002). The southern limit of the onshore Talara basin is the Paita high (Silla de Paita) but there are no obvious equivalent barriers present in the offshore portion. The basin is bounded to the north by the Dolores-Guayaquil megashear and the Pillars of Zorritos (Kraemer et al., 1999; Higley, 2004).

The Talara basin covers at least $15,000 \mathrm{~km}^{2}$, less than half of which is onshore (Figs. 1, 2) (Fildani, 2004). The onshore sedimentary deposits range from Cretaceous to Eocene in age (Fig. 3) and consist of clastic fill that is in excess of 9,000 $\mathrm{m}$ thick (Carozzi and Palomino, 1993). Middle-late Eocene strata of the Talara basin record a more complex story with a gradual deepening trend and deposition of deepwater systems. There was periodic extension after the Paleocene when subsidence was controlled by normal faulting allowing arc-related sediment to reach the basin only during periods of subsidence in the forearc region, probably related to plate rearrangement and/or seamounts colliding with the trench (Fildani et al., 2008). This subsidence was filled by siliciclastic sediment from multiple origins, predominantly from the east and the northeast (Fildani, 2004). Limited carbonate facies are restricted to parts of the Cretaceous and Pliocene-Pleistocene sections (Marsaglia and Carozzi, 1991; Carozzi and Palomino, 1993).

The oldest rocks in the region are those of the Amotape Formation (Fig. 3), which is exposed in the Amotape Mountains and consists of deformed Devonian to Permian age low-grade metamorphic rocks (Shepherd and Moberly, 1981). These rocks form an uplifted block along the eastern sides of both the Tumbes and Talara basins and are also reservoirs in the Talara basin (Fildani, 2004). Mesozoic rocks are not well exposed in any part of the basin and the few known outcrops are difficult to access. The rocks of the Cretaceous Muerto Formation unconformably overlie 


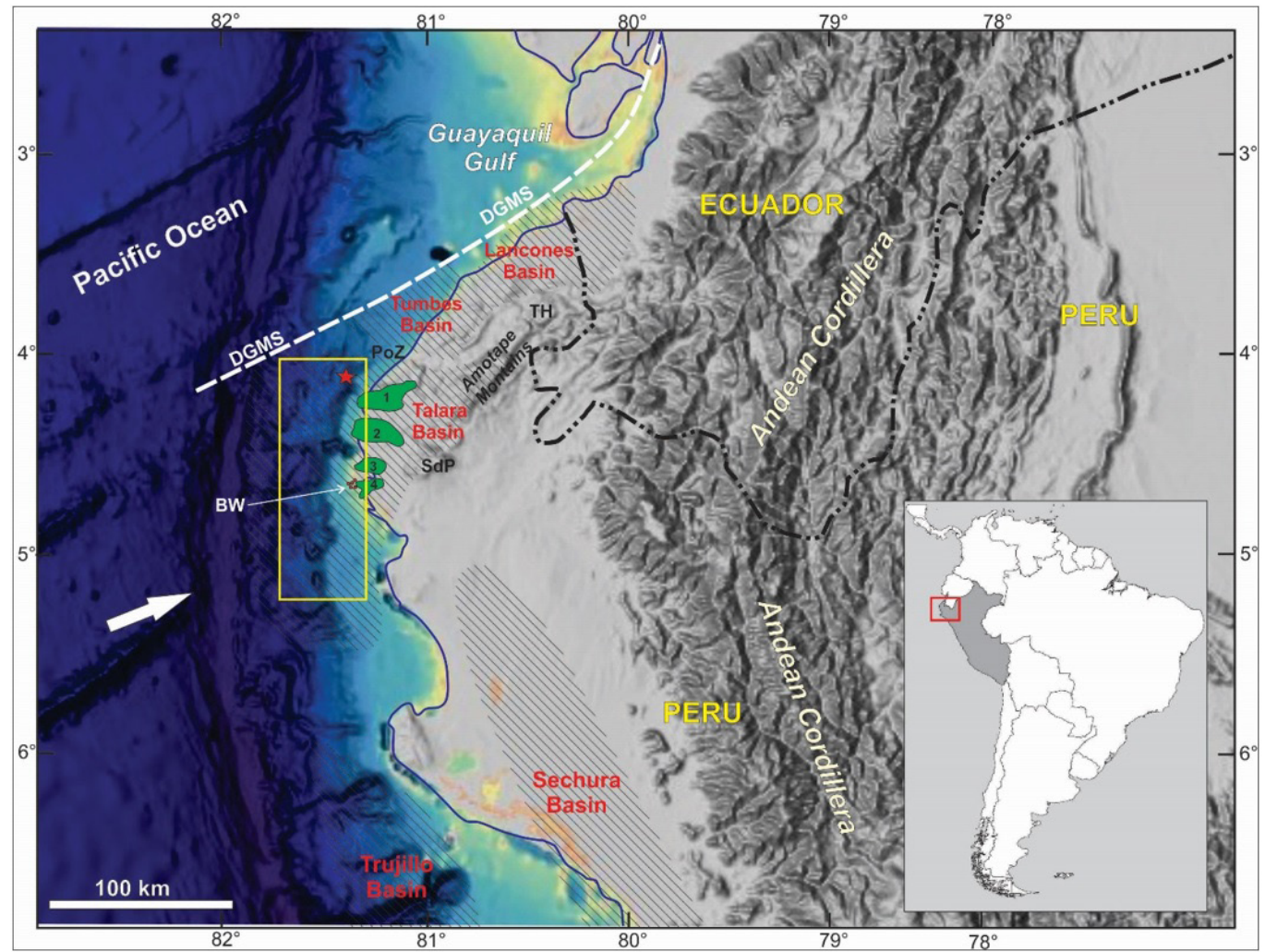

FIG. 1. The location of the Talara Basin, onshore Talara oil fields, Amotape Mountains and other features in northern Peru (SdP: Silla de Paita; PoZ: Pillar of Zorritos; TH: Tamarindo High; DGMS: Dolores-Guayaquil mega shear; BW: Belco Wells). 1. Los Organos-Peña Negra oil field; 2. Lobitos oil field; 3. Providencia oil field; 4. Litoral oil field. White arrow is the convergence direction of the subducted Nazca plate. Red star is the location of Prospect A. (topo-bathymetry from https://maps.ngdc.noaa. gov/viewers/bathymetry/ (Last visit: 12/06/2021)).

the Amotape Formation and consist of limestone and bituminous marl. The Muerto Formation is overlain by a series of Cretaceous and Paleocene siliciclastic units. Limited data from onshore suggest that the evolution is from a mixed carbonate-siliciclastic environment in the Aptian to a more restricted environment during the Albian for the rocks of the Muerto Formation (Daudt et al., 2010). During the Late Cretaceous (Campanian-Maastrichtian), alluvial fan and fluvial conglomerates and sandstones (i.e., Tablones Formation) were rapidly transgressed by distal shelf shales of the Redondo Formation (Daudt and Scherer, 2006). Various authors have suggested that shales and limestones of the Cretaceous are the petroleum source rocks for the Talara basin, mostly Muerto Formation bituminous marls and the Redondo Formation black shales (Seranne, 1987; ZúñigaRivero et al., 1999a, b; Arispe 2001a, b; Gonzales and Alarcón, 2002; Higley, 2004). Fildani et al. (2005) conclude that the main source rocks are not the Upper Cretaceous limestones, marls and black shales, but we believe the negative correlation is due to the fact that no Cretaceous rock samples were analyzed from the offshore Talara basin.

The coastline is marked by a series of raised Pleistocene to Quaternary age marine terraces (Tablazos) composed of transgressive limestone and coquina beds and covering about $60 \%$ of the onshore basin (Pedoja et al., 2006). These restrict the usefulness of onshore seismic in exploration (De Vries, 1988; Fildani et al., 2008), but are not present in the surveyed offshore.

Different tectonic models have been proposed for the coastal area of Ecuador and northwest Peru, reflecting the fact that the post-Paleozoic tectonic history of the area is complicated and not simply 


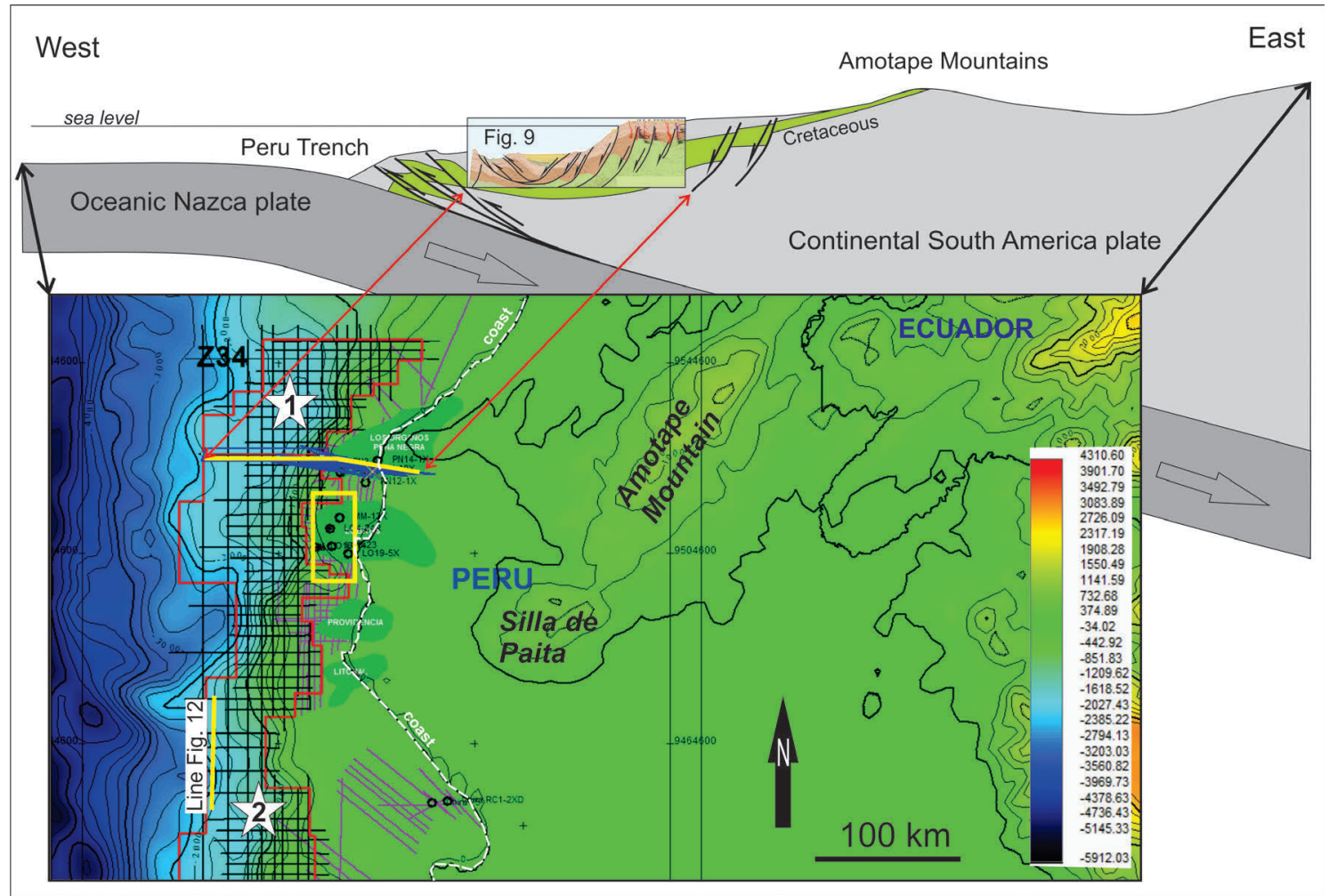

FIG. 2. The regional setting of the Talara Basin offshore portion immediately west of the traditional Talara oil fields, northern Peru. Yellow lines indicate the locations of seismic lines shown in figures 9 and 12. Two white stars within former Block Z-34 (red lines) show the locations of the two modeled pseudowells. Yellow rectangle is location of the Belco wells shown in figure 5.

related to subduction (Shepherd and Moberly, 1981; Jaillard et al., 1995; Bourgois et al., 2007). Aizprua et al. (2019) propose that the accretion of buoyant oceanic terranes may have had a profound impact on the early margin configuration of SW Ecuador and NW Peru. This led to the development of localized but genetically related forearc depocenters (sensu Dickinson, 1995) dominated by a Late Cretaceous (Peruvian Andean phase, Cobbold et al., 2007) deforming outer wedge. This tectonic phase was governed by plate instability followed by re-establishment of the margin by early Eocene (Incaic Andean phase: Cobbold et al., 2007). The resulting margin configuration and the spatial distribution of the different tectonic elements seem to have played a key role into the further Cenozoic (Quechua Andean phase) development of the forearc region. A more detailed account of basin evolution and sedimentary successions can be found in Fildani (2004) and Fildani et al. (2005).
This paper documents the petroleum system and exploration potential of the offshore portion of the Talara basin using the extensive knowledge of the onshore portion, and presents some of the prospective areas where success may be likely.

\section{Materials and methods}

The structural architecture of the former Z-34 block in the offshore area was interpreted using a 3D seismic reflection survey acquired in 2011 and wells provided by Perupetro S.A. Seismic interpretation was conducted using the Kingdom platform (Rossello et al., 2016).

We reconstructed the hydrocarbon generation and migration history in the offshore Talara Basin using the structure maps generated from the 3D seismic survey and integrated available geological and geochemical data into a georeferenced database. A conceptual geological model of the basin, using 


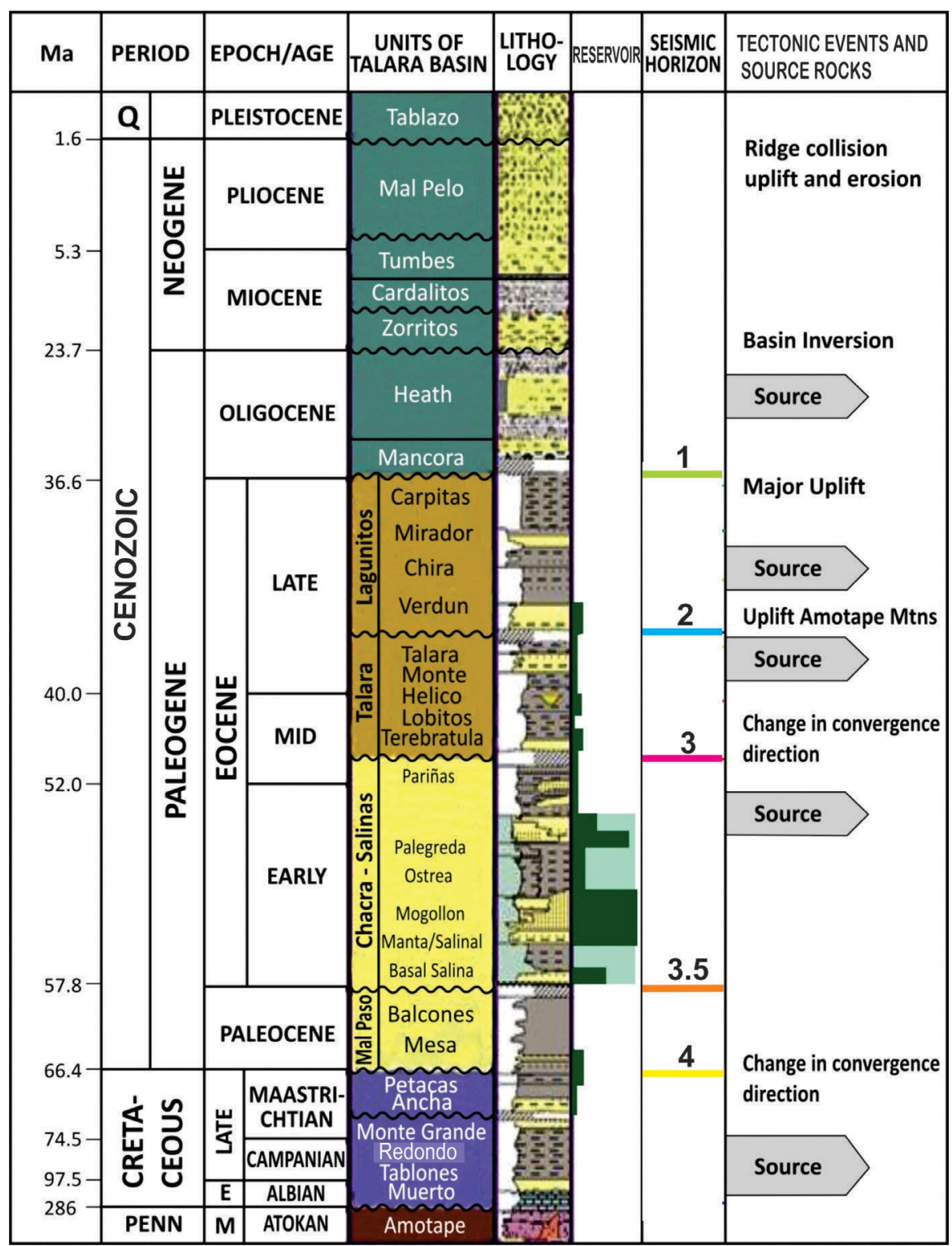

FIG. 3. Stratigraphic column of the Talara basin showing horizons mapped in the offshore part of the basin, main reservoir and source intervals. Seismic mapping horizons (1-4) are all unconformities. Modified from AIPC (no date), GonzalesTorres (1999), Kingston (1994), Kraemer et al. (1999), Perupetro (1999), and Seranne (1987). Light green: productive section (in dark green best reservoir levels). Lithology symbology from http:/www.kgs.ku.edu/PRS/Ozark/PROFILE/HELP/DATA_ENTRY/ lithology/Lithology-Symbols.html (Last visit: 12/06/2021).

only the major faults, was developed based on the interpretation of the 3D seismic survey calibrated by well data from the shallow marine platform and onshore oil fields. This model was then used to define a physical and temporal input necessary for petroleum system modeling (Magoon and Dow,
1994). Finally, an event chart was constructed showing the critical moments for the petroleum system.

The basin model (Hantschel and Kauerauf, 2009) was constructed using two pseudo wells (Fig. 4), chosen in the northern (Pseudowell 1) and southern 

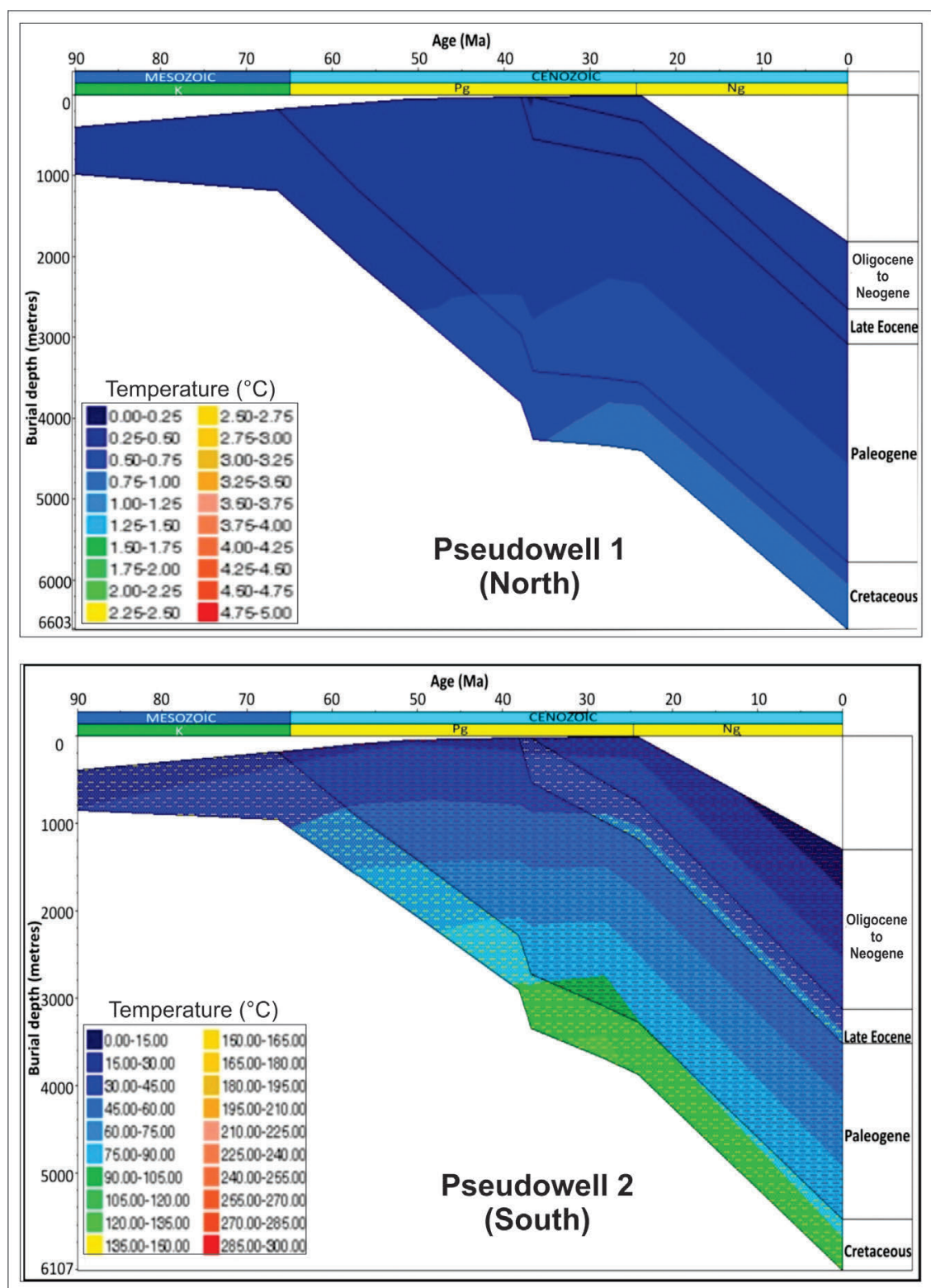

FIG. 4. Basin modelling for the pseudowells (see location in figure 2). This was chosen in the depocenter area of the block. Note that the Cretaceous enters the oil window (onset) at $39 \mathrm{Ma}$ and stays within it until present-day.

(Pseudowell 2) parts of former Block Z-34 where the thickest section of sediments is expected. The onset of maturity in Pseudowell 1 at $\mathrm{Vr}=0.63 \%$ was determined to be at 3,250 m (10,663 ft) depth bsl at about 39 My (Fig. 4). The onset of maturity at Pseudowell 2 at $\mathrm{Vr}=0.62 \%$ was determined to be at 3,285 m (10,778 ft) bsl at about $30 \mathrm{My}$. Both the northern and southern kitchens are in the oil generation window at the present-day. The maturity at Pseudowell 2 is confirmed by the oil present in the offshore and onshore Paita area in the Paleogene, Cretaceous and Paleozoic age reservoirs in the Talara Basin.

The chronostratigraphy for these pseudowell points was derived from the seismic interpretation and the modelled heat flow used was from the 
Perupetro (2005). They derived a heat flow for the present day of $32-37 \mathrm{~mW} / \mathrm{m}^{2}$ with heat flows as high as $35-48 \mathrm{~mW} / \mathrm{m}^{2}$ in the early Eocene which were calibrated to vitrinite reflectance data in various wells. However, it is likely that heat flow is not constant in the basin and may vary considerably from one area to another (Lemgruber-Traby et al., 2020). No sequence is identified which reaches gas maturity in the block.

\section{Petroleum system}

\subsection{Source rocks}

The main source rocks in the Talara basin are the Cretaceous (Campanian) black, marine shales of the Redondo Formation (with the Albian limestone of the Muerto Formation) and the marine shales of the Paleogene (Lemgruber-Traby et al., 2020) (Fig. 3). The Muerto Formation contains Type II and Type II-III kerogen and has a Total Organic Carbon (TOC) content of 1-4.5 wt\% (Perupetro, 2005).

The Campanian rocks of the Redondo Formation are the most volumetrically significant source rock in thickness and quality (Gonzalez and Alarcon, 2002) and contain Type II and Type II-III kerogen and 1-5.3 wt $\%$ TOC. It has excellent potential for hydrocarbon generation with a Hydrocarbon Index (HI) of over $400 \mathrm{mgHC} / \mathrm{g}$ TOC (Perupetro, 2005). It was deposited in an area of coastal upwelling and anoxic organic deposition (Pindell and Tabbot, 1995).

The Oligocene rocks of the Heath Formation are also believed to be a major source in the Tumbes and Trujillo Basins, but have been shown by burial history modeling to be immature in the Talara Basin (Lemgruber-Traby et al., 2020). Other minor source rocks are known to be present in the Eocene (Higley, 2004).

\subsection{Offshore reservoir rocks}

There are more than 40 oil and gas fields in the Talara basin province which produce from up to 12 reservoirs per well (Higley, 2004). The primary reservoirs are the Eocene-age nearshore marine sandstones. The primary target offshore is also expected to be the Eocene-age reservoirs, but their environment of deposition is expected to be deepwater (turbidites) with a source from the northeast to southeast from the highlands created from the compressional uplift of the Andes.

The Paleocene/Eocene sequence is expected to be entirely deepwater clastic (turbiditic) in nature. Eocene reservoirs have been penetrated by wells at the Peña Negra, Lobitos, Providencia and Litoral fields nearby and are known to contain turbidite sandstones (Laverde et al., 2010).

Rock properties of the Eocene Members and Formations are well documented onshore and in the shallow offshore areas (Table 1).

The rock properties of the reservoirs in offshore prospects may be better than those documented onshore because the Eocene turbidites should have better sorting and early migration of hydrocarbons may have preserved higher porosity and permeability values. Some better rock properties in the Pariñas Formation were observed in the Belco NHX-7 well, where up to $25 \%$ porosity was encountered (see Fig. 5 for location).

The Basal Salinas sandstones in the northern part of the onshore basin consist mainly of turbidite fans and incised valley fills that prograde to the southwest and northwest (Gonzales Torres, 1999).

An additional reservoir target offshore is the sandstones within the source interval of the Upper Cretaceous Redondo Shale and the Upper Cretaceous Ancha and Petacas Formations (Fig. 3). Four Talara Basin onshore fields produce hydrocarbons from

TABLE 1. AVERAGE ROCK PROPERTIES OF THE MAIN EOCENE RESERVOIR INTERVALS FROM BIANCHI (2002).

\begin{tabular}{ccc}
\hline Eocene Formation & Porosity & Permeability \\
\hline Helico (Talara Group) & $12-15 \%$ & $2-5 \mathrm{mD}$ \\
Pariñas & $11-19 \%(25 \%)$ & $60-120 \mathrm{mD}$ \\
Manta (Mogollon) & $8-11 \%$ & $0.15 \mathrm{mD}$ \\
Basal Salinas Sand & $11-16 \%$ & $14-20 \mathrm{mD}$ \\
\hline
\end{tabular}




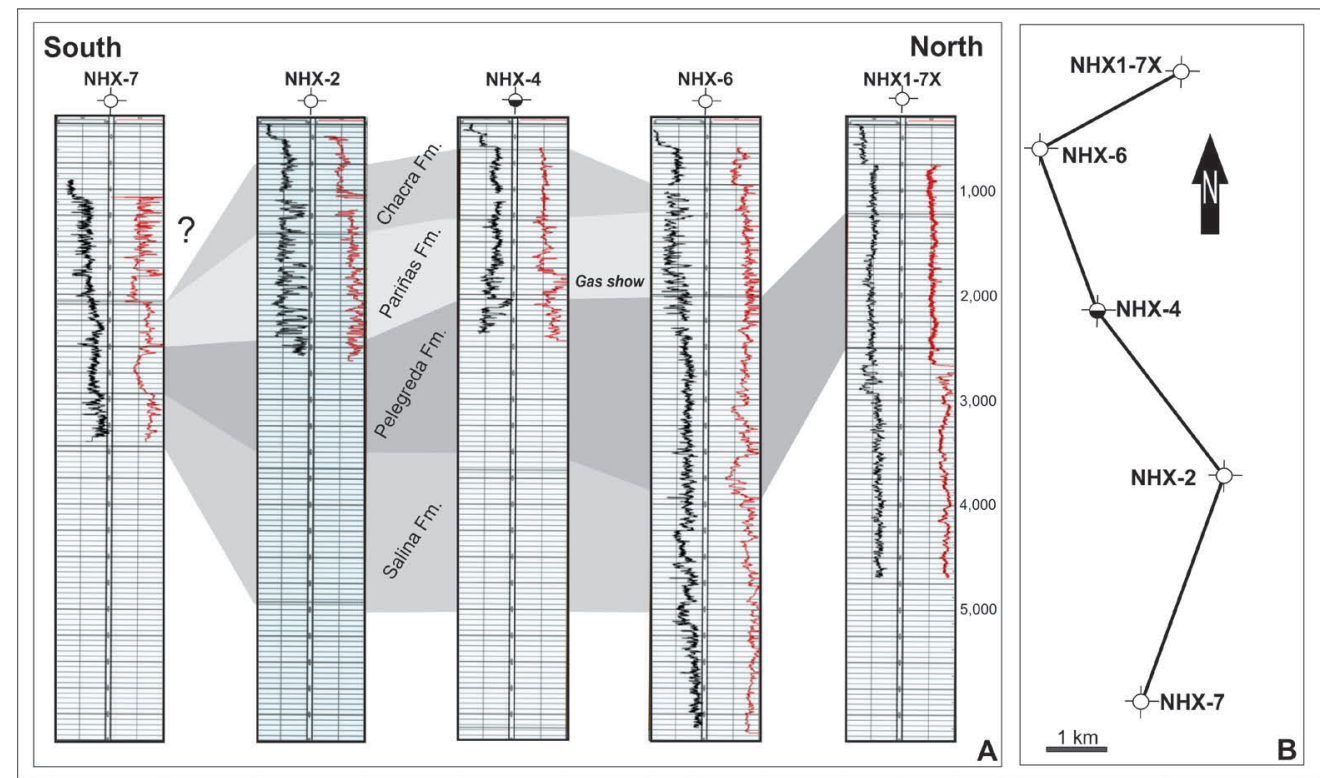

FIG. 5. A. Cross-section through five of the six Belco wells drilled in 1984 in shallow water on the eastern margin of Block Z-34 (Depths in feet). Note the gas shows within the Pariñas Formation which corresponds to U/C 3 mapping horizon. Log header: Gamma ray shown in black; Resistivity shown in red. B. Relative position of these wells (see figure 2 for location).

sandstones within the Cretaceous Redondo Shale and the Ancha and Petacas Formations and also from the basal Mal Paso Group (Fildani et al., 2005).

The Pennsylvanian meta-quartzites and metalimestones of the Amotape Formation (Fig. 3) can be a commercial reservoir when they are highly fractured (Grosso et al., 2005) and capped by the Cretaceous Redondo Shale. The now abandoned Zorro field produced about 100,000 bbls from the Amotape Formation metamorphic basement (Petroconsultants, 1996). The overlying Muerto, Tablones and Redondo Formations contain probable source rocks and these could be sources for oil in the Amotape reservoirs. When oil is found in the Amotape Formation rocks (Perupetro, 2005) its properties are very similar to the Cretaceous-sourced oils which suggests it was sourced from the same marine shales (Higley, 2004). Four Talara Basin fields produce hydrocarbons from quartzites of the Amotape Formation (Petroconsultants, 1996). Porosities and permeabilities will likely be low in the Amotape Formation.

\subsection{Seals}

The main seal overlying the early Eocene interval would be the upper Eocene shales of the Talara and
Lagunitos groups (Fig. 3). Shales in the early Eocene Chacra Formation are seals in the onshore Litoral field (Fildani et al., 2005). The Belco wells (Fig. 2) drilled in 1984 encountered the Pariñas Formation rocks (lower Eocene) with freshwater salinities indicating that the seals are intact.

\subsection{Hydrocarbon kitchens}

Thermal maturation modeling combined with structural mapping has shown that two hydrocarbon kitchens exist in the offshore Talara Basin (one in the north and another in the south (Figs. 2, 4)). The probable Cretaceous source rocks (Muerto and Redondo Formations) reached the onset of maturity ( $\mathrm{VR}=0.63 \%$ ) at a depth of 3,250 to $3,285 \mathrm{~m}$ $(10,663-10,778 \mathrm{ft})$ between 30 and $39 \mathrm{Ma}$ (Late Eocene to Oligocene). Importantly, the Cretaceous source rocks stay within the oil window once they enter it in the late Eocene and appear to stay within that maturity until the present-day.

The events chart (Fig. 6) indicates different potential source rocks in the Cretaceous (Muerto Limestone and Redondo shales) and Paleocene, Eocene and Oligocene Formations, which were deposited into the transition between oceanic and 


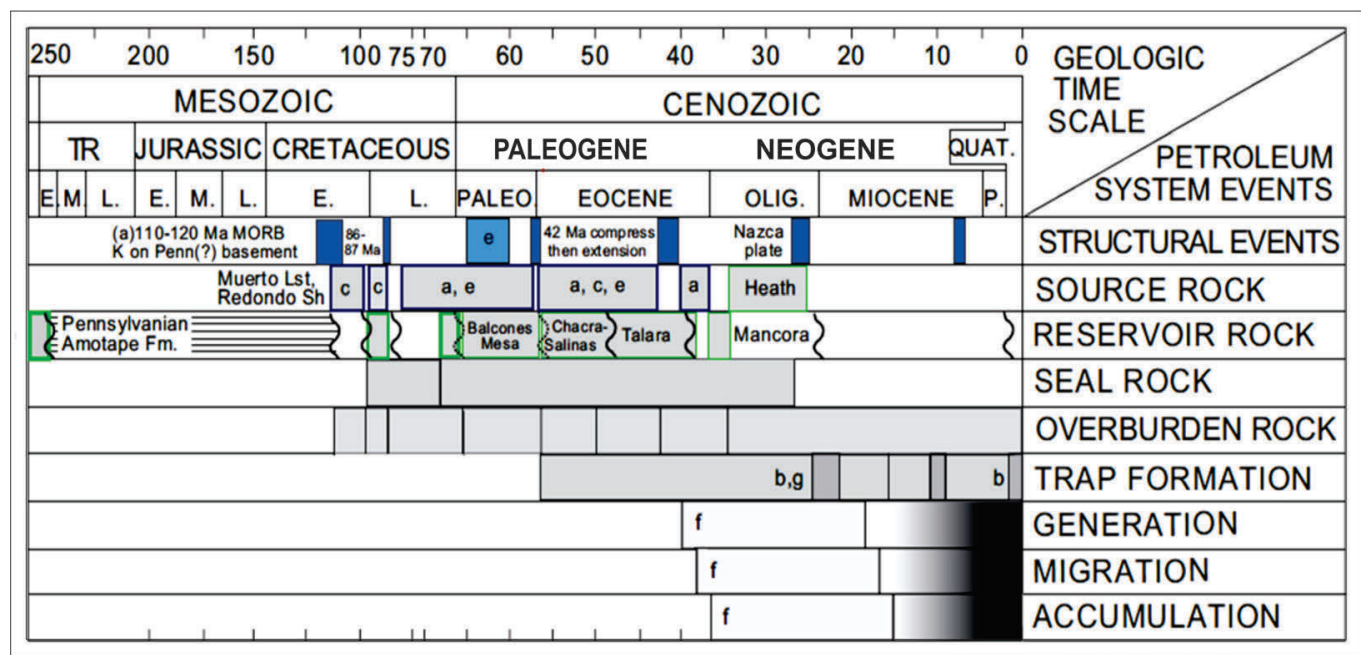

FIG. 6. Petroleum systems event chart of the Talara Basin Province indicating the petroleum system elements (source rock, reservoir, and seal), the timing of hydrocarbon generation, migration and accumulation, and the critical moment (taken from Higley, 2004). Letters a: AIPC (no author or date); b: Jaillard et al. (1995); c: Perupetro (1999); d: Petroconsultants (1996); e: ZúñigaRivero et al. (1999a, b); f: Kingston (1994); g: Shepherd and Moberly (1981). E: early; M: medium; L: late; Olig.: Oligocene; P.: Pliocene; Quat.: Quaternary.

continental lithosphere without direct influence of the active subduction. The seal rock ranges from Cretaceous to Oligocene in age and consists mainly of shales. The critical moment, or peak generation, is at $10 \mathrm{Ma}$.

These two hydrocarbon kitchens are the main locations of oil generation for the onshore and offshore in the Talara Basin. Cumulative oil production from current fields in the Talara Basin amounts to over 1,600 million bbl and a similar estimated amount remains to be discovered and produced. Modeling and source rock potential indicates offshore kitchens where few wells have been drilled in water depths exceed $100 \mathrm{~m}(328 \mathrm{ft})$.

\subsection{Migration}

The onset of migration from the Cretaceous source rocks probably took place in the late Eocene to Oligocene (39-30 Ma), as indicated by our basin modeling studies. Migration was mostly in an updip and easterly direction from the two offshore source kitchens via vertical and sub-vertical faults (Fig. 7). Structural and stratigraphic traps along the migration pathway would have preferentially filled first, before the traps of the onshore fields, such as Peña Negra and Los Organos, were filled.
Migration is still occurring today, as indicated by the sea-surface oil slicks mapped from satellite data (Fig. 8). Present-day oil seeps are shown to be occurring where a large down-to-the-west normal fault is expressed as a scarp on the sea floor (Fig. 7).

\section{Reservoir and target/prospect definition}

The Talara Basin contains a working petroleum system and has been producing from onshore fields such as Peña Negra, Lobitos, Providencia and Litoral since the mid-1800s. All the elements of the petroleum system are present: source, reservoir, seal and overburden. The components of the petroleum system are also present: the trap formation, generation, migration and accumulation.

The main potential Eocene reservoirs are characterized by alternating marine shales, sandstones, and conglomerates deposited during the early Paleogene. Many of the Eocene sandstone intervals are producing reservoirs onshore (Daudt and Scherer, 2006; Daudt et al., 2011). Normal faulting affected the basin extensively during and after deposition of the basin-fill and created the traps. Offshore mapping horizons are all unconformities within the Eocene as well as the unconformities at the top Paleocene and top Cretaceous (Fig. 3). Correlation from onshore 


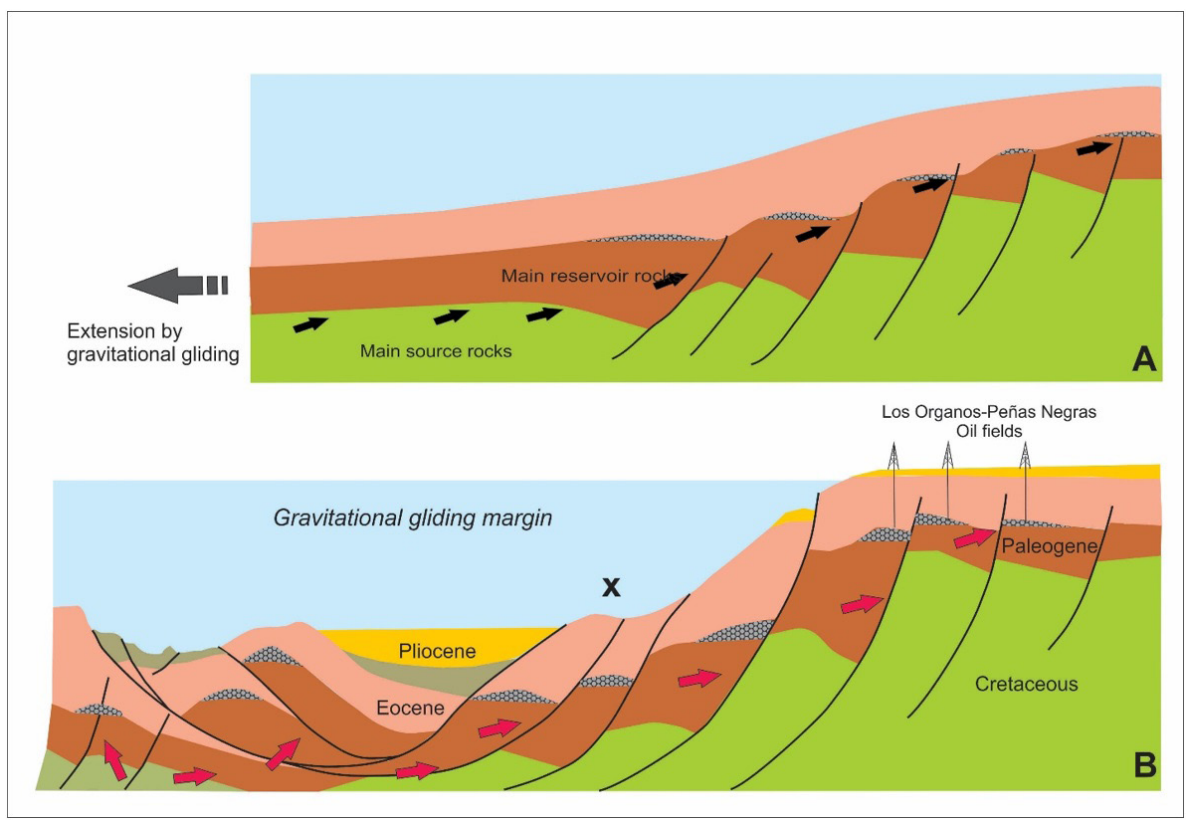

FIG. 7. E-W schematic diagram showing the evolution of the hydrocarbon migration from the offshore source kitchens to the traps in the Talara basin based on the figure 9 seismic lines (see location in figure 2). A. Early stage of migration (black arrows: estimated migration routes). B. Present-day migration pathway (red arrows), traps shown in gray. Sea floor scarp at $\mathbf{X}$ is where the present-day oil seep is located.

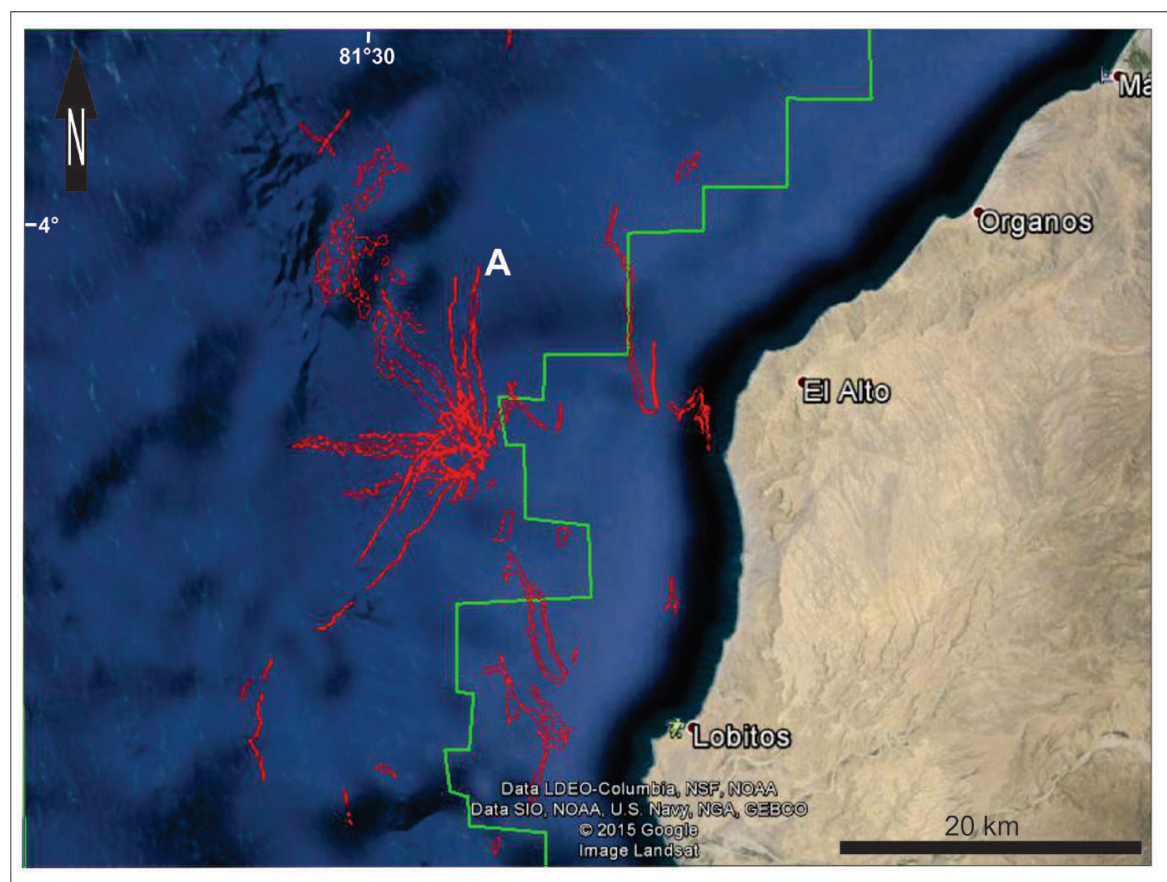

FIG. 8. Map showing radiating pattern based on satellite and radar scenes of present-day oil seeps on the water surface just to the south of Prospect A, showing that migration is occurring at the present-day from a point-source about $15 \mathrm{~km}$ south of Prospect A. Green line: eastern border of the former Z-34 Block. 
to offshore within the basin is difficult due to the lack of seismic data onshore and a lack of published formation tops and time/depth data (Fig. 9).

Many direct hydrocarbon indicators (DHIs) such as amplitude anomalies (AVO anomaly) and flat spots have been observed in the offshore portion of the Talara Basin. In Prospect A, located immediately west of the onshore Los Organos-Peñas Negras oil fields (Fig. 1) above the main prospective Eocene interval, an AVO anomaly was also observed above the top Eocene U/C 1 horizon (Fig. 10). This anomaly appears on the southwest flank of Prospect

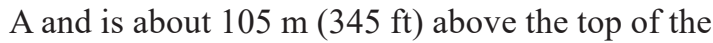
Eocene prospective interval and crosses structural contours, indicating there must be a stratigraphic component to the trap.

At the U/C 1 mapped horizon on the same structure of Prospect A there is an amplitude anomaly immediately below the crest of the structure on Prospect A (Fig. 11). There are also Eocene-Paleocene strong amplitude anomalies between horizons U/C 2 and U/C 3 which appear to onlap the U/C 3 structural high (Fig. 12). The older amplitudes are evident on the west side of high and do not conform to structure contours, suggesting a stratigraphic trapping element. Flat spots have also been identified at the downdip limits of the amplitude anomalies below $\mathrm{U} / \mathrm{C} 3$ and U/C 1 (Fig. 11).

The presence of gas hydrates offshore Peru was postulated by Miller et al. (1991) who evaluated 2D seismic data recorded by Shell in deep water offshore Lima and noted the presence of a Bottom Simulating Reflector (BSR). The origin of this gas is probably biogenic since the proposed Cretaceous source rocks are in within the oil window today. The 3D seismic data in former Block Z-34 also shows clear evidence of BSRs in sediments that appear to contain many sandstones of reservoir quality (Fig. 13). Mapping of the BSR and the water bottom on 3D data enabled the thickness of the gas hydrate zone within the sediments to be estimated. Figure 13 shows the gas hydrates to be between $525-579 \mathrm{~m}(1,722-1,900 \mathrm{ft})$ thick over Prospect A, based on velocity measurements

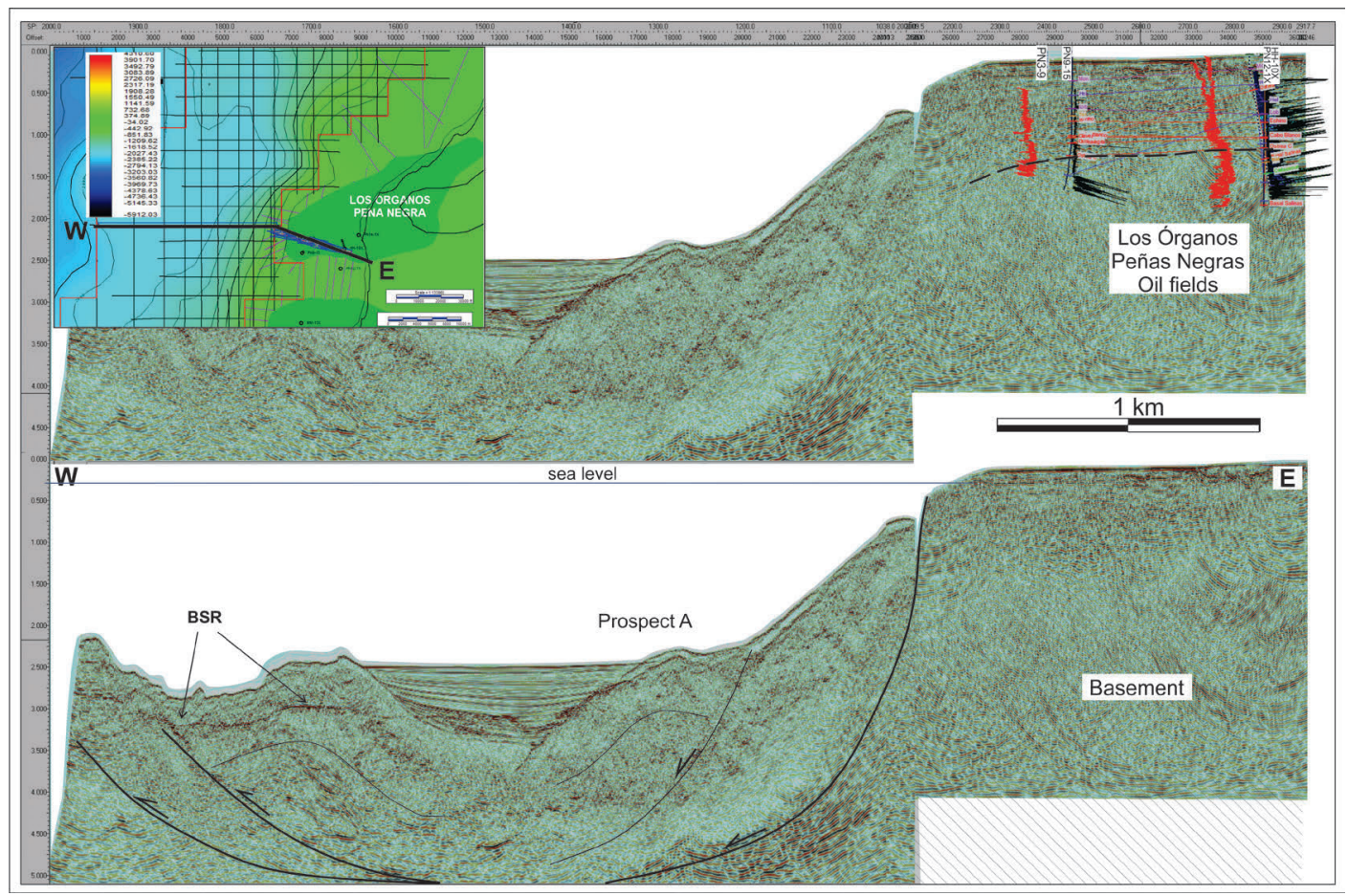

FIG. 9. W-E interpreted (lower) and uninterpreted (upper) cross-sections showing the correlation from onshore producing oil fields to the offshore Talara Basin and the position of the Prospect A. Well logs; Gamma ray in red and resistivity in black (LLD). Insect shows the location of the section. Dashed line is the estimated top of the basement. 

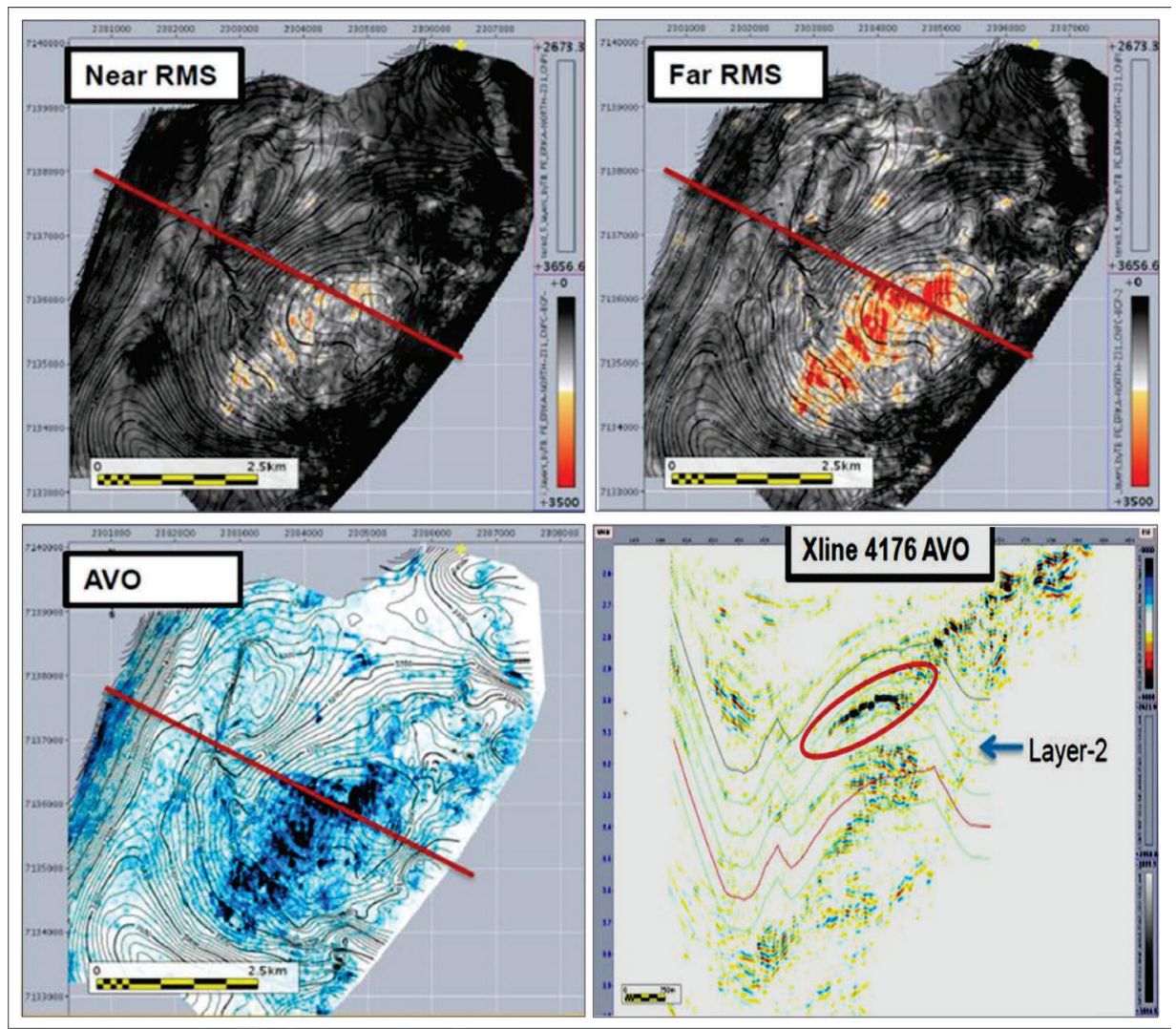

FIG. 10. Near and Far root mean square (RMS) amplitude anomalies on the southwest flank of Prospect A (see figure 1 for location). The anomaly is about $105 \mathrm{~m}$ above U/C 1 (top Eocene), in the Oligocene section. It crosses the structural contours, indicating a stratigraphic trapping component. Red line shows the position of the seismic line in figure 11. Red ellipse: strong AVO anomaly.

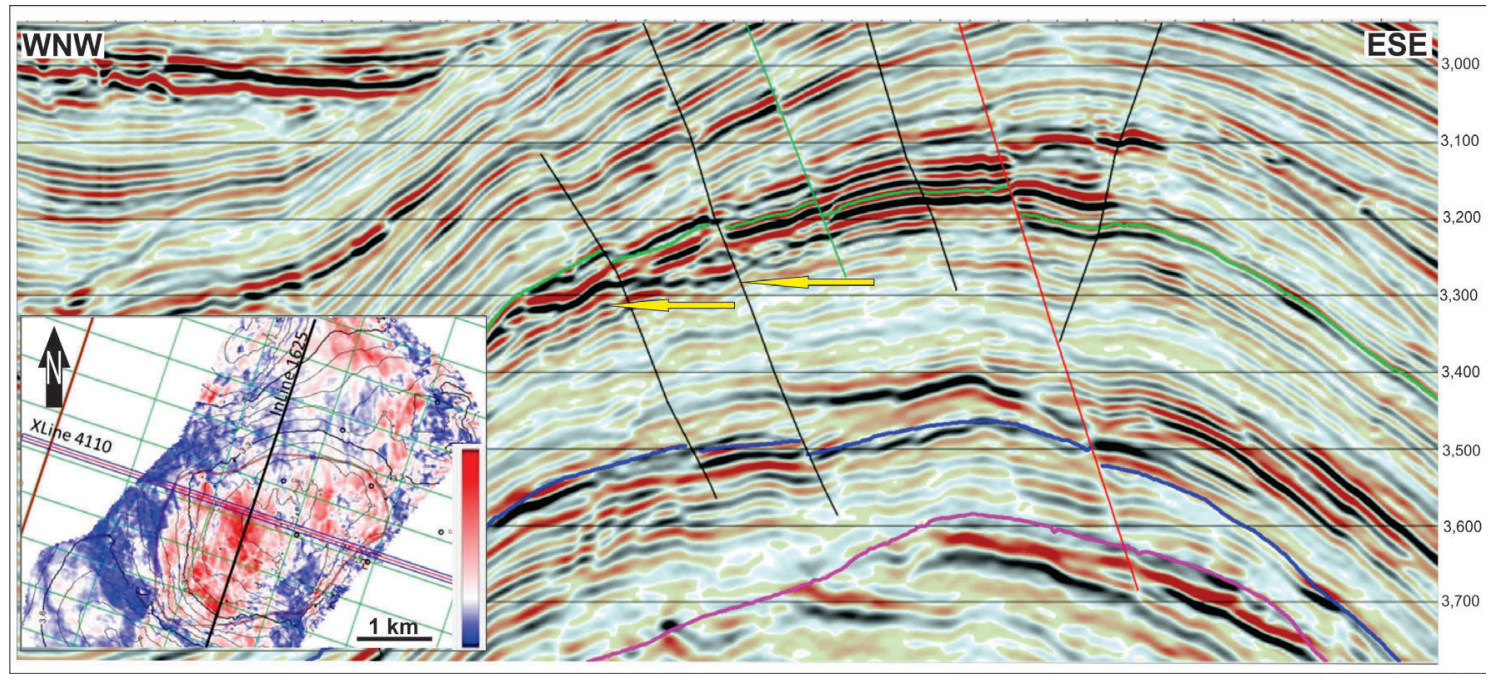

FIG. 11. Flat spots (yellow arrows) at the termination of the amplitude anomalies underlying U/C 1 (green line) in the XLine 4110 (see figure 13) at Prospect A (see location in figure 2). Vertical scale in milliseconds. Inset shows location of this line. Green, red and black are faults. 


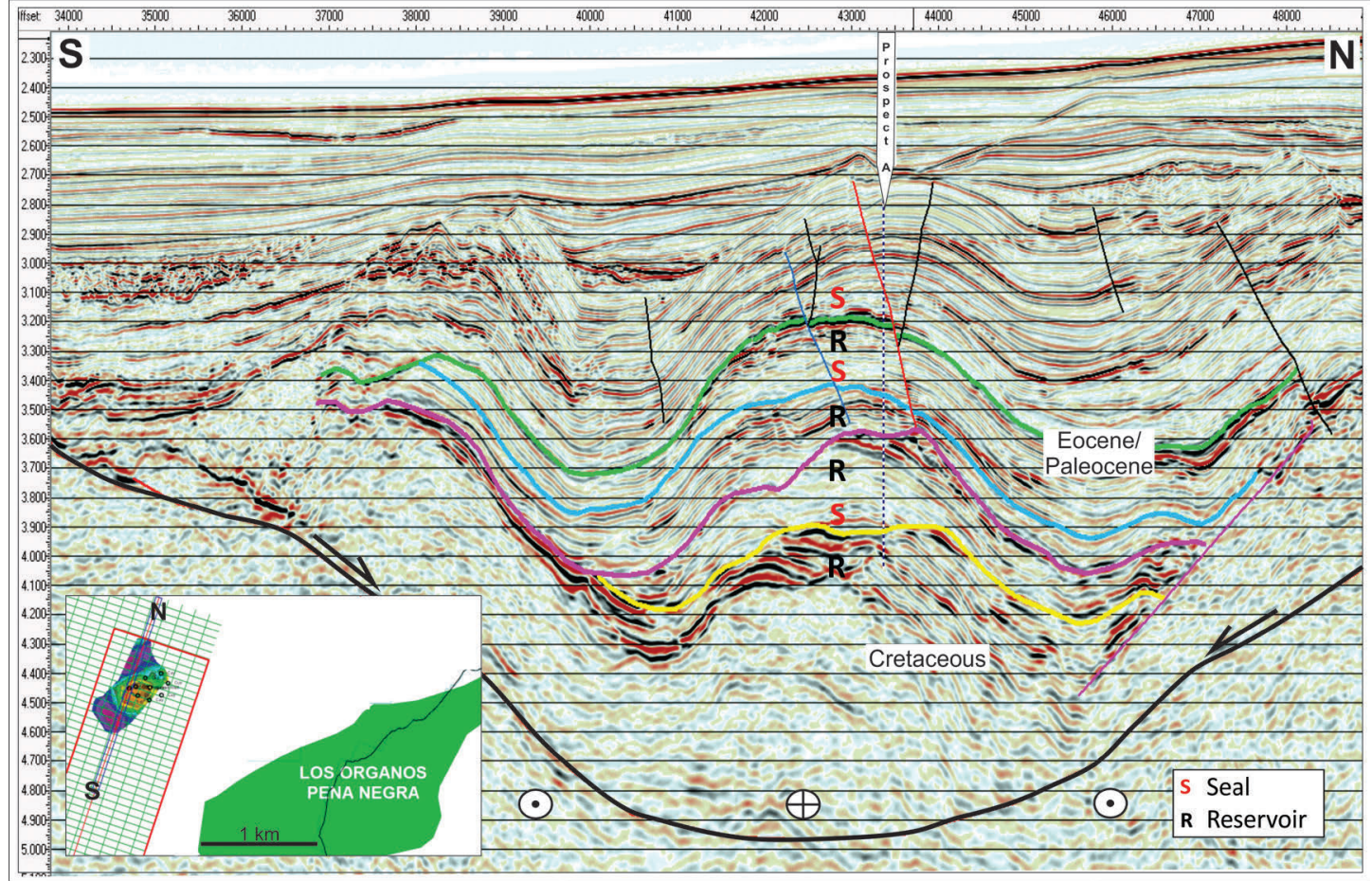

FIG. 12. North-South seismic line 1615 across Prospect A. This line shows the shape of the gravitational gliding toward west of the block, where Prospect A is located. See location in figures 1 and 13. R: Reservoir, S: Seal (inferred from transparent seismic facies). Yellow line: top Cretaceous; Violet line: U/C3 (top Pariñas Fm.); Blue line: U/C2 (top Talara Fm.); Green line: U/C1 (top Eocene).

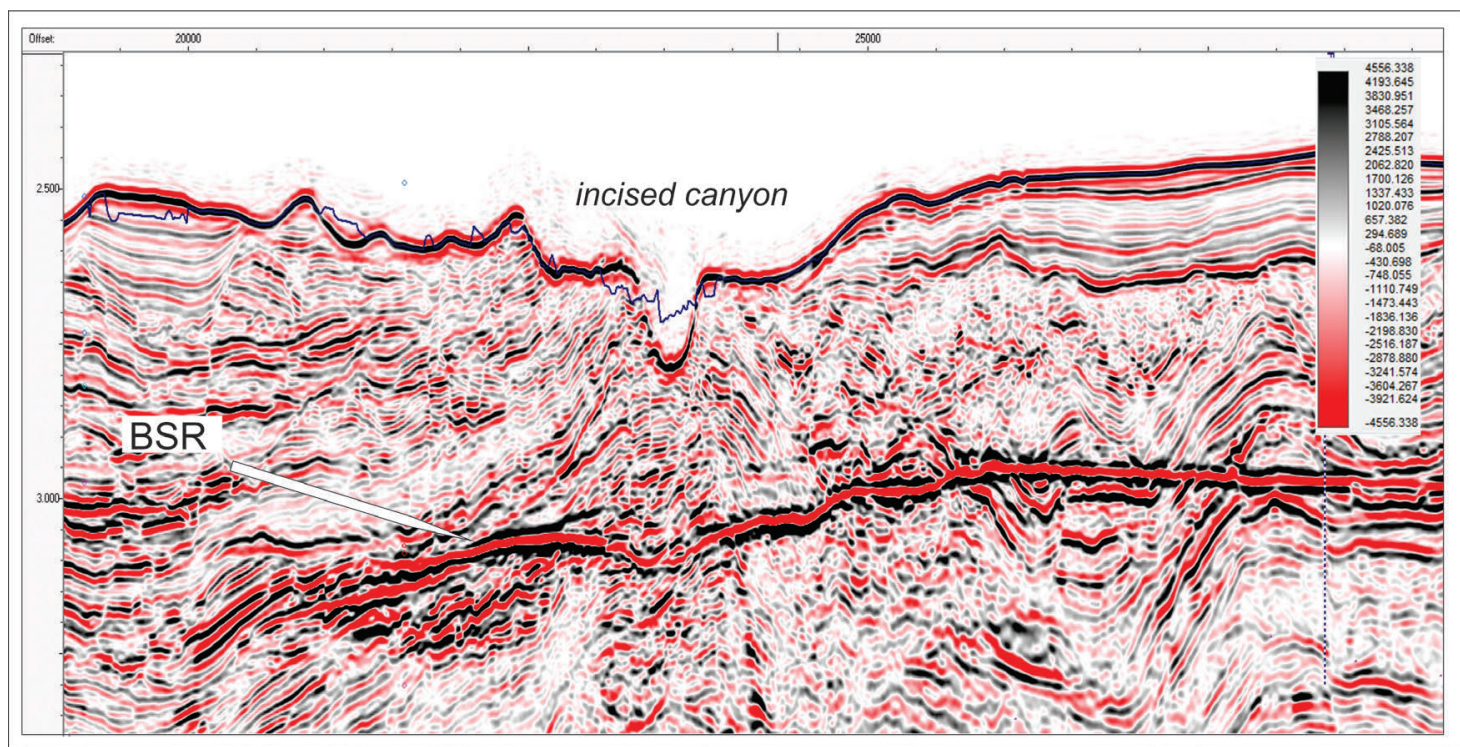

FIG. 13. A typical Bottom Simulating Reflector (BSR) near Prospect A. Seismic line location is shown in figure 2. 
from a group of wells with similar stratigraphy in the Gulf of Mexico (Birchwood et al., 2007).

At least six different play types were identified during the mapping of 3D data in the offshore Talara Basin: 1) Rollover anticline traps with Eocene reservoirs; 2) Tilted fault block closures with Eocene reservoirs; 3) Deep-seated anticlinal structures; 4) Stratigraphic traps with Eocene or Oligocene reservoirs; 5) Traps below the BSR. At least 23 prospects were identified in the basin.

One of the best prospects is a rollover anticline (Prospect A) located within a mini passive-margin setting, where a large down-to-the-west growth fault is mapped (Figs. 9, 13). Mapping shows that the trap at Prospect A is a structural high where the structure started to form during deposition of the main Eocene reservoir section due to the movement of the large growth fault to the east of the prospect (Fig. 14). The trap is a rollover anticline modified by intra-Eocene unconformities, which were used as the main mapping horizons (Fig. 14). It is located less than $20 \mathrm{~km}$ west of the producing Litoral field onshore in a water depth of $1,800 \mathrm{~m}$.
Several unconformities throughout the Eocene reservoir section confirm that the structure started to form in the early Eocene. The four unconformities used in seismic mapping are also shown on figure 3. Three are within the Eocene and one is at the top of the Cretaceous. The structure is present on all mapping horizons down to the top Cretaceous. The main reservoir section is the Eocene Talara Formation, the top of which is at about $39 \mathrm{Ma}$. Therefore, the reservoir and the trap formed at the ideal time, just before the onset of maturity in the Cretaceous source rocks. Our thermal modeling presented here suggests it is unlikely that the Cretaceous source rocks have entered the gas window.

\section{Conclusions}

The offshore Talara basin in Peru is an extension of the onshore working petroleum system that has been explored and has produced in excess of 1.68 billion barrels of oil in the last 130 years. During our study of the offshore and based on the interpretation of the $1,100 \mathrm{sq} \mathrm{km}$ of marine $3 \mathrm{D}$ seismic survey (acquired in 2011) we identified at least 23 prospects

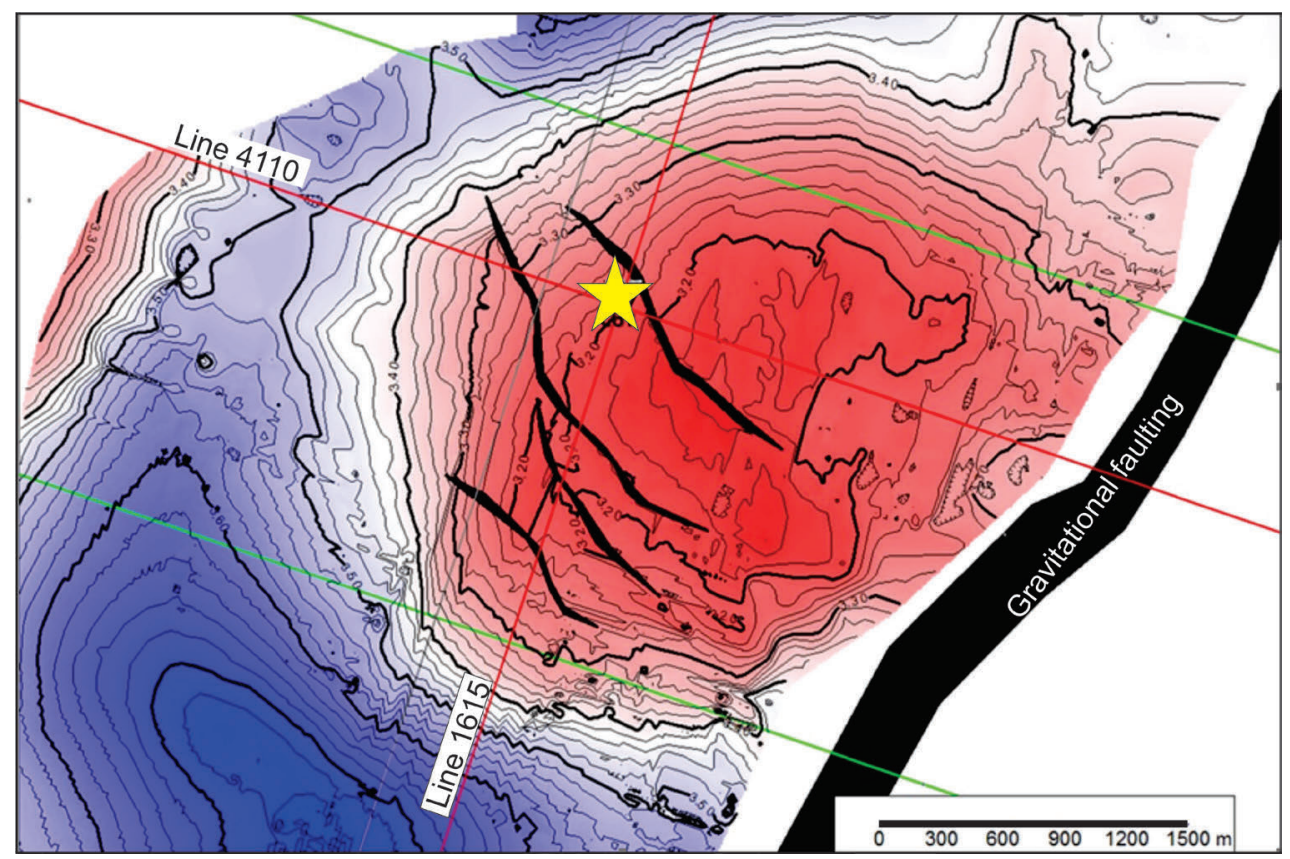

FIG. 14. Structure map on top of U/C 1 at Prospect A (see location in figure 9). Yellow star is the proposed well location. Red lines: seismic lines shown in figures 11 and 14. Green lines: grid of the former Z34 Block. The thick black lines represent the large normal fault, downthrown to the west. 
in 6 different plays confirming the offshore Talara Basin offers excellent exploration opportunities. One of the best prospects, Prospect A, is located within a mini passive-margin setting in a water depth of $1,800 \mathrm{~m}(5,905 \mathrm{ft})$ and could be tested with a well with a total depth of about $4,200 \mathrm{~m}$ $(13,700 \mathrm{ft})$ with a top reservoir section estimated to be at about $2,700 \mathrm{~m}(8,860 \mathrm{ft})$.

Potential reservoirs are interpreted to be up to $700 \mathrm{~m}(2,300 \mathrm{ft})$ thick with predicted porosities up to $25 \%$ due to better sorted sediments and porosity preserved by early hydrocarbon charge. Deeper targets are also thought to be the Upper Cretaceous sandstones in the Redondo Shale, Ancha and Petacas Formations. Another deeper reservoir target might be the fractured low-grade metamorphic rocks of the Amotape Formation, which have produced hydrocarbons in the onshore Talara basin.

The main hydrocarbon source is interpreted to be the Cretaceous (Albian-Campanian) shales, which started generating hydrocarbons at about $39 \mathrm{Ma}$. The migration pathway was easterly from the two offshore source kitchens and is still occurring today as shown by the sea floor oil seeps. The best prospects are located on the migration pathway between the source kitchens and the Talara Basin onshore oil fields.

The risk of the presence of hydrocarbons in the offshore basin has been reduced due to the presence of amplitude anomalies in structural and combination traps and the identification of multiple flat spots at the downdip limits of these anomalies. The trapping risk has been reduced due to the interpretation of older unconformity traps which would have been present at the time of migration in approximately the Late Eocene to Oligocene.

Despite the fact that the studied area is located on a tectonically active subducting margin, the presence of preserved mini basins on its accretional prism generates an interesting hydrocarbon system to sustain an attractive and underexploited exploration objective.

\section{Acknowledgements}

The authors would like to thank UOGG Company for access to the data shown in this paper and former UOGG colleagues and partners with whose permission this paper is published. We acknowledge Dr. Y. Calderón, and anonymous reviewer and also the Editor for the constructive comments which greatly helped us improve the original manuscript.

\section{References}

Aizprua, C.; Witt, C.; Johansen, S.E.; Barba, D. 2019. Cenozoic stages of forearc evolution following the accretion of a sliver from the Late CretaceousCaribbean Large Igneous Province (CLIP): SW Ecuador-NW Peru. Tectonics 38 (4): 1441-1465. doi: 10.1029/2018TC005235.

AIPC. no date. A review of the petroleum potential of the Tumbes Basin, Peru. Denver, Colorado. American International Petroleum Corporation: $46 \mathrm{p}$.

Arispe, A. 2001a. Peru offshore 1: Peru offers deep-water blocks south of Talara area. Oil \& Gas Journal 99 (8): 25-29.

Arispe, A. 2001b. Peru offshore 2: Tumbes -Talara blocks off Peru may signal deep-water play in turbidites. Oil \& Gas Journal 99 (7): 21-24.

Bianchi, R.C. 2002. Sistema petrolero, mecanismos de entrampamiento de fluidos en el campo Litoral, Cuenca Talara-noroeste del Perú: Lima, Perú. INGEPET Seminar, EXPR-3-CB-02.pdf, 14 p.

Birchwood, R.; Noeth, S.; Jones, E. 2007. Safe drilling in Gas-Hydrate prone sediments: findings from the 2005 Drilling Campaign of the Gulf of Mexico Gas Hydrates Joint Industry Project (JIP): USDOE-NEL. Methane Hydrate Newsletter 8 (1): 1-4.

Bourgois, J.; Bigot-Cormier, F.; Bourles, D.; Braucher, R.; Dauteuil, O.; Witt, C.; Michaud, F. 2007. Tectonic record of strain buildup and abrupt co-seismic stress release across the northwestern Peru coastal plain, shelf, and continental slope during the past $200 \mathrm{kyr}$. Journal of Geophysical Research 112: BO4104. doi: 10.1029/2006JB004491.

Carozzi, A.V.; Palomino, J.R. 1993. The Talara forearc basin: Depositional models of oil-producing Cenozoic clastic systems. Journal of Petroleum Geology 16 (1): 5-32.

Cobbold, P.R.; Rossello, E.A.; Roperch, P.; Arriagada, C.; Gómez, L.A.; Lima, C. 2007. Distribution, timing, and causes of Andean deformation across South America. In Deformation of the continental crust: The legacy of Mike Coward. (Ries, A.C.; Butler, R.W.H.; Graham, R.H.; editors). Geological Society of London, Special Publications 272: 321-343. London.

Daudt, J.; Scherer, C.M. 2006. Arquitetura de fácies e evolução estratigráfica dos reservatórios flúvio-deltaicos da Formação Echinocyamus (Eoceno Inferior) na área do Lote 10 (Bacia de Talara, Noroeste do Peru). Boletim de Geociências da Petrobras 14: 27-45.

Daudt, J.; Pozo, G.; Torres, K.; Ore, L. 2010. Evolução estratigráfica, arcabouço estrutural e potencial 
remanescente das unidades produtoras da Bacia de Talara (noroeste do Peru) na área do Lote X. Boletim de Geociências da Petrobras 18: 69-95.

Daudt, J.; Rejas, J.; Eris, G.; Galloso, J.; Huapaya, C.; Grobav, C. 2011. Integration of Sedimentology and Stratigraphy in a 3D Static Model: Example from the Echinocyamus Formation in the Block X, Talara Basin, NW Perú. American Association of Petroleum Geologists, Search and Discovery 20099: 50 p.

De Vries, T.J. 1988. The geology of late Cenozoic marine terraces (Tablazos) in northwestern Peru. Journal of South American Earth Sciences 1: 121-136.

Dickinson, W.R. 1995. Forearc basins. In Tectonics of sedimentary basins (Busby, C.J.; Ingersoll, R.V.; editors). Blackwell Science: 221-261. Oxford.

Diniz, S.H.; De Sá, F.R.; Rodríguez, C.; Santos, C.G.; Cruz, J.M.N.; Beas, W.E. 2010. Talara Basin, Peru: Structural and Stratigraphic Characterization Based on 3D-Seismic Data. Society of Petroleum Engineers, SPE 139283: 8 p.

Espurt, N.; Brusset, S.; Baby, P.; Henry, P.; Vega, M.; Calderon, Y.; Ramírez, L.; Saillard, M. 2018. Deciphering the Late Cretaceous-Cenozoic structural evolution of the North Peruvian forearc system. Tectonics 37: 251-282. doi: 10.1002/2017TC004536.

Fildani, A. 2004. Analysis of two arc-associated basins and onset of their deep-water stages: Magallanes basin, Chile, and Talara basin, Peru. Ph.D. Thesis, Stanford University (California): $325 \mathrm{p}$.

Fildani, A.; Hanson, A.D.; Zhengzheng Chen; Moldowan, J.M.; Graham, S.A.; Arriola, P.R. 2005. Geochemical characteristics of oil and source rocks and implications for petroleum systems, Talara basin, northwest Peru. American Association of Petroleum Geologists Bulletin 89 (11): 1519-1545.

Fildani, A.; Hessler, A.M.; Graham, S.A. 2008. Trenchforearc interactions reflected in the sedimentary fill of Talara basin, northwest Peru. Basin Research 20: 305-331.

Gonzales Torres, E.R. 1999. Modelo sedimentario de la formación Basal Salina, cuenca Talara: Lima, Peru. INGEPET '99 seminar, 1 CD-ROM, EXPR-1-EG-13: 16 p.

Gonzales, E.; Alarcón, P. 2002. Potencial hidrocarburífero de la cuenca Talara. Lima, Peru. INGEPET 2002 seminar, EXPR-1-EG-07: 15 p.

Grosso, S.; Marchal, D.; Gaudt, J. 2005. Integración afloramiento-subsuelo: Relación entre la complejidad estructural y el comportamiento productivo de los reservorios del Lote X, Cuenca Talara, Perú. INGEPET EXPL-1-SG-147: 12 p.
Hantschel, T.; Kauerauf, A.I. 2009. Fundamentals of basin and petroleum systems modeling. Springer: $476 \mathrm{p}$. Berlin. doi: 10.1007/978-3-540-72318-9.

Higley, D. 2004. The Talara basin province of northwestern Peru. Cretaceous-Tertiary total petroleum system. United States, Geological Survey, e-bulletin B-2206a: 52 p. http://pubs.usgs.gov/bul /2206/A/. (Last visit 10/04/2021).

Hinostroza, C.; Espinoza, U. 2005. Incremento de producción mediante la rehabilitación y seguimiento de pozos abandonados en campos maduros: un ejemplo - Lote X, Talara- Perú. V ${ }^{\circ}$ INGEPET (EXPL-4-CH-150): 12 p.

Jaillard, E.; Ordóñez, M.; Benítez, S.; Berrones, G.; Jiménez, N.; Montenegro, G.; Zambrano, I. 1995. Basin development in an accretionary, oceanic-floored forearc setting: southern coastal Ecuador during Late Cretaceous-Late Eocene time. In Petroleum basins of South America (Tankard, A.J.; Suarez Soruco, R.; Welsink, H.J.; editors). American Association of Petroleum Geologists Memoir 62: 615-631.

Kingston, J. 1994. Undiscovered petroleum of southern South America. United States, Geological Survey Open-File Report 94-559: 443 p.

Kraemer, P.; Weiner, A.; Álvarez, P. 1999. Evolución tectonoestratigráfica de la cuenca de Tumbes-Progresooffshore Perú. Exploration and exploitation of petroleum and gas: Lima, Peru. INGEPET, EXPR-1-PK- 07: 9 p.

Laverde, F.; Pozo, G.; Miranda, F.; Sánchez, W.; Torres, K.; Carrillo, G.; Álvarez, J.L.; Contreras, F. 2010. Detailed facies definition and 3D static model: Reservoir management of the Eocene producing units in Block $\mathrm{X}$ of the Talara Basin in Northwest Peru. Society of Petroleum Engineers, SPE 139181: 18p.

Lemgruber-Traby, A.; Espurt, N.; Souque, C.; Henry, P.; Calderon, Y.; Baby, P.; Brusset, S. 2020. Thermal structure and source rock maturity of the North Peruvian forearc system: Insights from a subductionsedimentation integrated petroleum system modeling. Marine and Petroleum Geology 122. doi: 104664. 10.1016/j.marpetgeo.2020.104664.

Magoon, L.B.; Dow, W.G. 1994. The petroleum system. In The petroleum system-From source to trap (Magoon, L.B.; Dow, W.G.; editors). American Association of Petroleum Geologists, Memoir 60: 3-23.

Marsaglia, K.M.; Carozzi, A.V. 1991. Depositional environment, sand provenance, and diagenesis of the basal Salina Formation (lower Eocene), NW Peru. Journal South American Earth Sciences 3: 253-267.

Miller, J.J.; Lee, M.W.; Von Huene, R. 1991. An analysis of a seismic reflection from the base of a gas hydrate 
zone, Offshore Peru. American Association of Petroleum Geologists, Bulletin 75 (5): 910-924.

Pedoja, K.; Ortlieb, L.; Dumont, J.F.; Lamothe, M.; Ghaleb, B.; Auclair, M.; Laborusse, B. 2006. Quaternary coastal uplift along the Talara Arc (Ecuador, Northern Peru) from new marine terrace data. Marine Geology 228: 73-91.

Petroconsultants, 1996. Petroleum exploration and production and PetroWorld 21 databases: Petroconsultants, Inc., Houston.

Perupetro, 1999. Offshore and coastal blocks. International bidding round, Lima, Peru. Perupetro information booklet (San Borja, Lima): 47 p.

Perupetro, 2005. Tumbes and Talara basins, hydrocarbon evaluation. In Basin Evaluation Group Exploration Department (Martínez, E.; Coordinator): 290 p. Lima.

Pindell, J.L.; Tabbot, K.D. 1995. Mesozoic-Cenozoic Andean paleogeography and regional controls on hydrocarbon systems. In Petroleum basins of South America (Tankard, A.J.; Suárez Soruco, R.; Welsink, H.J.; editors). American Association of Petroleum Geologists, Memoir 62: 101-128.

Rossello, E.A.; Cossey, S.; Fernández, G. 2016. The Talara offshore (Northern Peru): a preserved extensional mini- basin in a subduction complex. Simposio Bolivariano de Cuencas Subandinas, No. 12, Actas 1: 1-6. Bogotá.

Seranne, M. 1987. Evolution tectono-sedimentaire du Bassin de Talara (nord-ouest du Perou). Bulletin de l'Institut Français des Études Andines 16 (3-4): 103-125.

Shepherd, G.L.; Moberly, R. 1981. Coastal structure of the continental margin, northwest Peru and southwest Ecuador. Geological Society of America Memoir 154: 351-391.

Travis, R.B.; Gonzales, G.; Pardo, A. 1975. Hydrocarbon potential of coastal basins of Peru. American Association of Petroleum Geologists, Memoir 25: 331-338.

Valencia, K.; Uyen, D. 2002. Cuenca Lancones: Interpretación geológica. INGEPET-Perupetro, EXPR-3-KV-18. Extended abstract: 4 p.

Zúñiga-Rivero, F.; Hay-Roe, H.; Vargas, T. 1999a. Talara: A new look at an old petroleum basin. Exploration and exploitation of petroleum and gas: Lima, Peru. INGEPET, EXPR-1-FZ-15: 9 p.

Zúñiga-Rivero, F.; Hay-Roe, H.; Vargas, T. 1999b. Peru's coastal basin-5 (conclusion), Potential untested under 50 million acres in Peru. Oil \& Gas Journal 97 (11): 67-72.

Manuscript received: February 18, 2021; revised/accepted: July 14, 2021; available online: September 30, 2021. 